\title{
GCU
}

Glasgow Caledonian

University

University for the Common Good

\section{A new index for assessing the contribution of energy efficiency in LEED 2009 certified green buildings to achieving UN sustainable development goals in Jordan}

Alawneh, Rami; Ghazali, Farid; Ali, Hikmat; Asif, Muhammad

Published in:

International Journal of Green Energy

DOI:

$10.1080 / 15435075.2019 .1584104$

Publication date:

2019

Document Version

Author accepted manuscript

Link to publication in ResearchOnline

Citation for published version (Harvard):

Alawneh, R, Ghazali, F, Ali, H \& Asif, M 2019, 'A new index for assessing the contribution of energy efficiency in LEED 2009 certified green buildings to achieving UN sustainable development goals in Jordan', International Journal of Green Energy, vol. 16, no. 6, pp. 490-499. https://doi.org/10.1080/15435075.2019.1584104

\section{General rights}

Copyright and moral rights for the publications made accessible in the public portal are retained by the authors and/or other copyright owners and it is a condition of accessing publications that users recognise and abide by the legal requirements associated with these rights.

Take down policy

If you believe that this document breaches copyright please view our takedown policy at https://edshare.gcu.ac.uk/id/eprint/5179 for details of how to contact us. 

achieve United Nations Sustainable Development Goals in Jordan. 2

Abstract

Water and energy efficiency are given high priority in all green building assessment systems. However, a method to assess and improve their contributions to achieve the United Nations (UN) Sustainable Development Goals (SDGs) has not been developed. This research aims to fill this gap. At the time of this research, most certified green buildings in Jordan were under Leadership in Energy and Environmental Design (LEED) v2.2 new construction. The relationships between the LEED v2.2 "water efficiency" (WE) and "energy and atmosphere" (EA) standards and the UN SDGs were explored using a quantitative descriptive methodology. Structured questionnaire surveys yielded 55 responses from Jordanian building industry experts. Pearson's Chi-square and frequency tests were carried out to examine these relationships. We propose a new Comprehensive Contribution to Development Index (CCDI) to assess the contributions of the implementation of LEED v2.2 WE and EA to achieve the UN SDGs. The results show a positive relationship between LEED v2.2 prerequisites and credits in both WE and EA categories with the UN SDGs 6-9, 12-13, and 15, suggesting that the proposed CCDI is a reliable and robust tool for the evaluation of the contribution of water and energy efficiency in LEED v2.2- certified green buildings to achieving the UN SDGs in Jordan.

Keywords: Energy, water, green building, United Nations, sustainable development 24 goal, LEED

\section{Introduction}

On September 25, 2015, 193 members of the United Nations (UN) adopted the UN sustainable development goals (UN SDGs), which aim to eliminate discrimination and inequality, end poverty, and overcome climate change by 2030 [1]. Numerous economic and social-developmental concerns, such as health, poverty, hunger, education, gender equality, climate change, water, sanitation, environment, energy, and social justice, are covered by the 17 UN SDGs [2].

The construction industry significantly contributes to national socioeconomic development. This industry uses a considerable amount of natural and energy resources. Hence, the active participation of this industry in a country's efforts to attain sustainable development is essential [3].

Worldwide, the construction and building sectors constitute $40 \%$ of the total energy use, $40 \%$ of waste, $30 \%$ of energy-related greenhouse gas emissions, and $12 \%$ of water consumption and employ $10 \%$ of the labor force. Many local and global challenges, such as demographic shifts, climate change, water, land use, and other resource shortages, are significantly affected by the built environment. Fast-growing regions in Asia, Latin America, and Africa are predicted to have additional 2 billion urban residents by 2030. This rapid population increase leads to a pressing demand for sustainable construction and buildings [4].

The society, environment, and economy are three areas that are considerably affected 
buildings highlights the importance of conducting environmental assessments of buildings in the construction industry [5].

The construction industry is vital for social progress, economic growth, and successful environmental protection, which are the three elements of sustainable development [6]. "Green building," as defined by the Environmental Protection Agency, is "the practice of creating structures and using processes that are environmentally responsible and resource-efficient throughout a building's life-cycle from siting to design, construction, operation, maintenance, renovation, and deconstruction." [7].

Governments worldwide have adopted green buildings as a key policy to avert energy crises and climate change [8]. The World Green Building Council stated that "green buildings can contribute to meeting the sustainable development goals;" information and infographics on the website of the World Green Building Council show how green buildings can contribute to achieving 9 of the UN SDGs [9].

Sustainable development may be achieved through the implementation and application of green-building-assessment tools [10]. Sustainable construction refers to construction that is economically, socially, and environmentally sustainable [11]. Developed by the United States Green Building Council (USGBC), the Leadership in Energy and Environmental Design (LEED) is a nongovernmental certification program, which has been widely adopted worldwide [12]. This program has helped to establish the green building rating system worldwide, with the goal of guaranteeing energy efficiency and decreasing the negative environmental impacts of buildings [13]. This rating system for green buildings promotes a unified approach to design and acknowledges the importance of building design features in improving sustainability. Such design features include reduced energy use, protected construction sites, improved indoor environment quality, the utilization of sustainable materials, and decreased water consumption [14]. Based on the success of LEED as a green building rating system, the LEED v2.2 (specifically reacting to new construction) was introduced in 2005. So far, this upgraded version has certified over 5,000 projects worldwide [15]. The LEED v2.2 rates projects in six categories: energy and atmosphere (17 points); indoor environmental quality (15 points); sustainable sites (14 points); materials and resources (13 points); water efficiency ( 5 points); and innovations and design process ( 5 points) [16]. The total sum of LEED points determines the certification level awarded to a specific project: Platinum (52-69); Gold (39-51); Silver (33-38); and Certified (2632) [17].

The UN has classified Jordan as a lower-middle-income nation. The gross domestic product (GDP) per capita of Jordan in 2016 was 4087.9 US dollars. The population of Jordan increased from 5,597,000 in 2004 to $9,798,000$ in 2016, with over $80 \%$ residents in urban areas. In 2016, the construction sector of Jordan contributed 4.4\% to the GDP, equal to an additional 1,195.8 million JD. This sector also employed approximately $6.1 \%$ of the total Jordanian labor force. In the same year, the number of buildings with permits reached 7,576 [18]. Water scarcity is a serious concern in Jordan, a problem that affects every industry that requires water to sustain its production activities and thus achieve success [19]. The overdependence of Jordan on imported energy and its escalating energy demand have become serious challenges to Jordan's ability to secure a stable energy supply [20]. 
Survival, economic growth, and human progress require two factors that are intricately

linked: water and energy. Water is essential for production processes of energy sources

(including electricity) such as raw-material extraction, cleaning processes, cooling thermal processes, crop cultivation for biofuels, and powering turbines. Energy is necessary to ensure that water resources are available for human consumption (including irrigation) through treatment, pumping, transportation, and desalination. The various resolutions regarding water and energy challenges should be organized into an integrated response because partial responses are bound to fail in the long term despite short-term success. The promotion of alternatives that solve energy problems but aggravate water scarcity, the improvement of the access to water at the expense of exacerbating energy problems or, worse, the advancement of alternatives that improve the access to energy and water but affect the environment should be avoided [21].

At the time of this research (September 2016), there were only four certified LEED

1) World Health Organization Building, LEED BD+C: New Construction v2 - LEED 2.2, certification awarded in December 2011 [22].

2) Dutch Embassy in Amman, LEED BD+C: New Construction v2 - LEED 2.2, certification awarded in October 2010 [23].

3) Middle East Insurance Building, LEED BD+C: New Construction v3 - LEED 2009, certification awarded in March 2014 [24].

Because more than one LEED-certified building is required for this study and most of the certified green buildings in Jordan are under new LEED v2.2 construction, we selected the LEED v2.2 new construction to investigate the relationship between water and energy efficiency in green buildings and the UN SDGs.

The contributions of water and energy efficiency in green buildings to achieve the UN SDGs in Jordan have not been assessed before. This research attempts to fill this gap.

Our main objectives are:

1. to identify the contributions of the implementation of LEED v2.2 prerequisites and credits in the WE and EA categories to achieve the UN SDGs in Jordan

2. to develop an integrated index for the assessment of the contribution of water and energy efficiency in LEED-v2.2-certified green buildings to achieve the UN SDGs in Jordan

Following this introduction, Section 2 reviews the literature from which the hypotheses are derived. The research methods are presented in Section 3. The results and discussion are provided in Section 4 and Section 5 concludes this paper.

\section{Literature review and hypothesis development}

\subsection{Relationship between LEED v2.2 credits in the WE category and the UN SDGs} natural resources. It is classified as semiarid to arid country and its annual rainfall is less than $200 \mathrm{~mm}$ over $92 \%$ of the land area. The total land area of Jordan is 89,297 $\mathrm{km}^{2}, 92 \%$ of which comprises deserts/rangeland [26]. The water scarcity in Jordan leads to significant challenges with respect to its development. The country's climatic conditions, geography, and geopolitical environment add to such challenges. A serious 
challenge that affects the wellbeing, security, and economic future of all Jordanians is posed by water scarcity [26].

Jordan currently faces water scarcity. In the population-resource equation, water plays a dominant role. In Jordan, the water resources continue to decline as the country's population continues to rise. An imbalance has thus emerged between the rapidly increasing population, which also comprises refugees, and actual water availability. The severe water shortage in Jordan is a result of the lack of natural surface water resources in the region. Recent severe drought periods have further aggravated the problem [27]. The amount of water available to citizens is simply not enough to sustainably support the growing population.

As identified by the U.S. Green Building Council (USGBC), the WE components of the LEED rating system have the main objective to "reduce the amount of potable water 163 consumed in buildings" [28]. The LEED WE category addresses the water issue by considering indoor use, outdoor use, specialized uses, and metering [28]. The water efficiency credits of LEED v2.2 (new construction) [28] are shown in Fig. 1.

Designers and builders can construct green buildings that use significantly less water than building based on conventional construction methods by incorporating native landscapes that eliminate the need for irrigation, installing water-efficient fixtures, and reusing wastewater for non-potable water needs [28].

Based on the Green Building Market Impact Report 2009, 1.2 trillion gallons (4.54

Because Jordan is a water-scarce country and potable water is the highest-ranking

- H1: There is a significant relationship between the UN SDGs and LEED v2.2 credits in the WE category.

We also investigated the following sub-hypotheses:

- H1A: There is a significant relationship between SDG6 and LEED v2.2 credits in the WE category.

- H1B: There is a significant relationship between SDG8 and LEED v2.2 credits in the WE category.

- H1C: There is a significant relationship between SDG9 and LEED v2.2 credits in the WE category.

- H1D: There is a significant relationship between SDG12 and LEED v2.2 credits in the WE category.

- H1E: There is a significant relationship between SDG13 and LEED v2.2 195 credits in the WE category.

- H1F: There is a significant relationship between SDG15 and LEED v2.2 
Fig. 1 shows the proposed links between the implementation of the LEED-v2.2 WE credits and UN SDGs 6, 8, 9, 12-13, and 15. 
Results of implementation of LEED v2.2 NC Water Efficiency credit

\begin{tabular}{|c|}
\hline $\begin{array}{l}\text { WE Credit 1.1: Water Efficient Landscaping: } \\
\text { Reduce by 50\% } \\
\text { Intent: Limit or eliminate the use of potable } \\
\text { water, or other natural surface or subsurface } \\
\text { water resources available on or near the project } \\
\text { site, for landscape irrigation. }\end{array}$ \\
\hline $\begin{array}{l}\text { WE Credit 1.2: Water Efficient Landscaping: } \\
\text { No Potable Water Use } \\
\text { or No Irrigation } \\
\text { Intent: Eliminate the use of potable water, or } \\
\text { other natural surface or subsurface water } \\
\text { resources available on or near the project site, } \\
\text { for landscape irrigation. }\end{array}$ \\
\hline $\begin{array}{l}\text { WE Credit 2: Innovative Wastewater } \\
\text { Technologies } \\
\text { Intent: Reduce generation of wastewater and } \\
\text { potable water demand, while increasing the } \\
\text { local aquifer recharge. }\end{array}$ \\
\hline $\begin{array}{l}\text { WE Credit 3.1: Water Use Reduction: } 20 \% \\
\text { Reduction } \\
\text { Intent: Maximize water efficiency within } \\
\text { buildings to reduce the burden on municipal } \\
\text { water supply and wastewatersystems. }\end{array}$ \\
\hline $\begin{array}{l}\text { WE Credit 3.2: Water Use Reduction: } 30 \% \\
\text { Reduction } \\
\text { Intent: Maximize water efficiency within } \\
\text { buildings to reduce the burden on municipal } \\
\text { water supply and wastewater } \\
\text { systems. }\end{array}$ \\
\hline
\end{tabular}

Reduce generation of wastewater
UN SDGs

\section{SDG6}

Ensure availability and sustainable

Reduce the amount of potable
water consumed in buildings.
and increase recycling and reuse of wastewater.

Create employment opportunities by development, production and use of development, production and use of
innovative water and wastewater innovative w
technologies.

Reduce building operation cost.

Reduce the energy required to treat water for potable use, transport it to and from a building, and treat it for disposal. Reduce greenhouse gas emissions associated with energy emissions
saving.

SDG8

Promote sustained, inclusive and sustainable economic growth, full and productive employment and decent work for all.

\section{SDG9}

Build resilient infrastructure, promote inclusive and sustainable industrialization and foster innovation.

\section{SDG12}

Ensure sustainable consumption and production patterns

Take urgent action to combat climate change and its impacts

\section{SDG15}

Take urgent action to combat climate change and its impacts

References : Jordan Context [18], Water Shortage in Jordan [19,20,26,27], Water and Energy [21],Green building and sustainable development [3,4, $5,6,7,8,9,10,11]$, LEED [12,13,14,15,16,17,22,23,24,25, 28, 29], UN SDGs [1,2].

Fig. 1. Proposed links between the LEED v2.2 WE credits and UN SDGs. 
The demand for energy and electricity is on the rise in Jordan [26]. This demand

becomes more complex by the limited availability of locally sourced fossil fuels, inadequate conversion capacities, and the absence of energy companies with strong financial capabilities. The rapid industrialization and population growth, which includes refugees from various regions, further aggravate the situation [27].

Projection results indicate that the consumption of electricity in Jordan will exceed the nation's capability for electricity generation [28]. More than $96 \%$ of Jordan's energy is imported in the form of crude oil products. In 2014, the cost of consumed energy represented $86.8 \%$ of exports, $27.7 \%$ of imports, and $17.6 \%$ of the GDP [20]. The per capita energy consumption between 2010 and 2014 increased from 1,204 to 1,272 kWh; in the same period, the per capita consumption of electricity increased from 2,101 to $2,318 \mathrm{kWh}$ [20]. Jordan imported energy equivalent to 8,449,000 t of oil in 2014; the energy generated from locally available resources, that is, mainly natural gas and renewable energy, reached an equivalent of $265,800 \mathrm{t}$ of oil [20].

The transportation sector is the major consumer of energy in Jordan; its energy consumption is approximately $46 \%$ of the total consumption. The residential sector, which consumes approximately $21 \%$ of the total energy ranks in second place; it is followed by the industrial sector with an energy consumption of approximately $20 \%$ of the total consumption [20].

Natural gas is the main source of electricity in Jordan and comprises approximately $70 \%$ of the total amount of electricity produced in the country. Heavy fuel oil and diesel are still utilized in some electric power plants [20].

In terms of electricity consumption, the residential sector in Jordan uses approximately $43 \%$ of the total electricity in the country, making it the leading electricity consumer. The residential sector is followed by the industrial sector with a consumption of $25 \%$, the commercial sector with a consumption of $15 \%$, the water pumping sector with a consumption of $15 \%$, and street lights with a $2 \%$ consumption [20]. This distribution shows that buildings in Jordan consume approximately $58 \%$ of the total electricity in the nation [20].

The LEED v2.2 EA category approaches energy from a holistic perspective, addressing energy-use reduction, energy-efficient design strategies, and renewable energy sources. The LEED V2.2 EA prerequisites and credits are shown in Fig. 2. Focusing on design that reduces the overall energy needs in a green building is the starting point to achieve energy efficiency. Considerations must be made in various areas such as the building orientation, glazing selection, and choice of climate-appropriate building materials. Strategies, such as passive heating and cooling, natural ventilation, and high-efficiency HVAC systems, combined with smart controls further reduce the energy use of a building. The generation of renewable energy on the project site or the purchase of green power allows portions of the remaining energy consumption to be met with nonfossil fuel energy, lowering the demand for traditional sources [28]. The commissioning process is critical to ensure high-performing buildings. The early involvement of a commissioning authority helps to prevent long-term maintenance issues and waste of 
energy by verifying that the design meets the owner's project requirements and intended functions [28].

The LEED-certified green buildings address energy savings by reducing the amount of

When buildings consume energy efficiently, the amount of greenhouse gas emissions

- H2: There is a significant relationship between the UN SDGs and LEED v2.2 267 prerequisites and credits in the EA category. 268

We also investigated the following sub-hypotheses: 269

- H2A: There is a significant relationship between SDG7 and LEED v2.2 270 prerequisites and credits in the EA category. $\quad 271$

- H2B: There is a significant relationship between SDG8 and LEED v2.2 272 $\begin{array}{ll}\text { prerequisites and credits in the EA category. } & 273\end{array}$

- H2C: There is a significant relationship between SDG9 and LEED v2.2 274 prerequisites and credits in the EA category. $\quad 275$

- H2D: There is a significant relationship between SDG12 and LEED v2.2 276 prerequisites and credits in the EA category. 277

- H2E: There is a significant relationship between SDG13 and LEED v2.2 278 $\begin{array}{ll}\text { prerequisites and credits in the EA category. } & 279\end{array}$

Fig. 2 shows the proposed links between LEED v2.2 EA prerequisites and credits and 280 $\begin{array}{ll}\text { the UN SDGs. } & 281\end{array}$ 


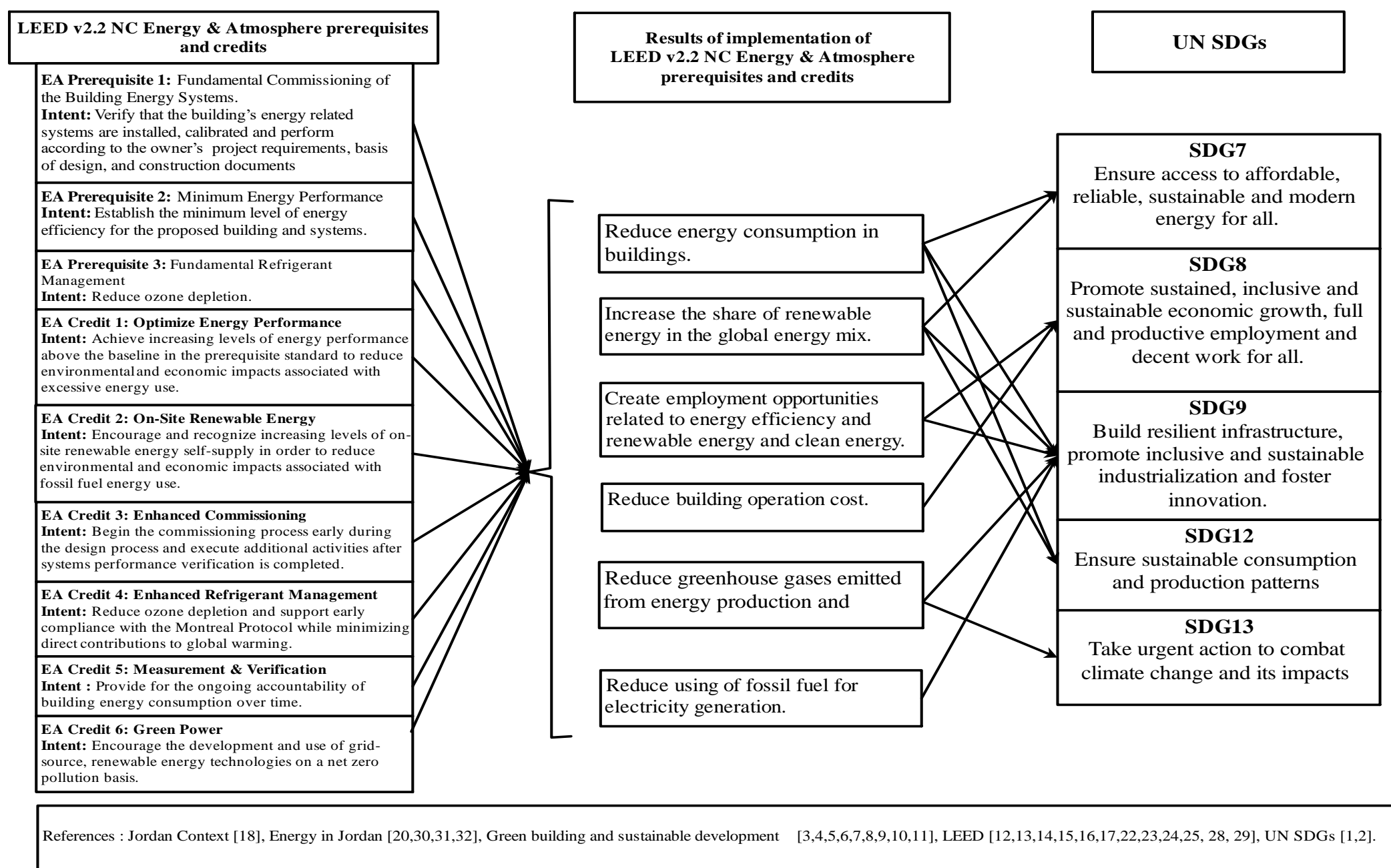

Fig. 2. Proposed links between LEED v2.2 EA prerequisites and credits and the UN SDGs. 
Based on the United Nations World Water Development Report 2014, Water and

Energy Volume 1, "Water and energy are strongly interlinked: water is required to

produce, transport, and use all forms of energy to some degree and energy is required

Research on the water-energy nexus is increasing significantly [34]. Jiangyu et al.

identified 70 studies on the water-energy nexus by conducting an extensive literature survey [34]. Siddiqi et al. developed a framework to bridge decision networks for integrated water and energy planning; this framework was successfully used in the case study for Jordan [35]. Water and energy resource challenges in Jordan require creative methods to manage these resources in an integrated sustainable manner. Integrated management of interdependent water and energy systems at the building scale is critical to achieve sustainable development. Hence, the connections between water and energy efficiency in green buildings should be considered in Jordan to achieve the UN SDGs. Therefore, this research aims to develop an integrated index for assessing and improving the contributions of water and energy efficiency in green buildings. Fig. 3 shows the proposed integrated links between LEED v2.2 EA prerequisites and credits 


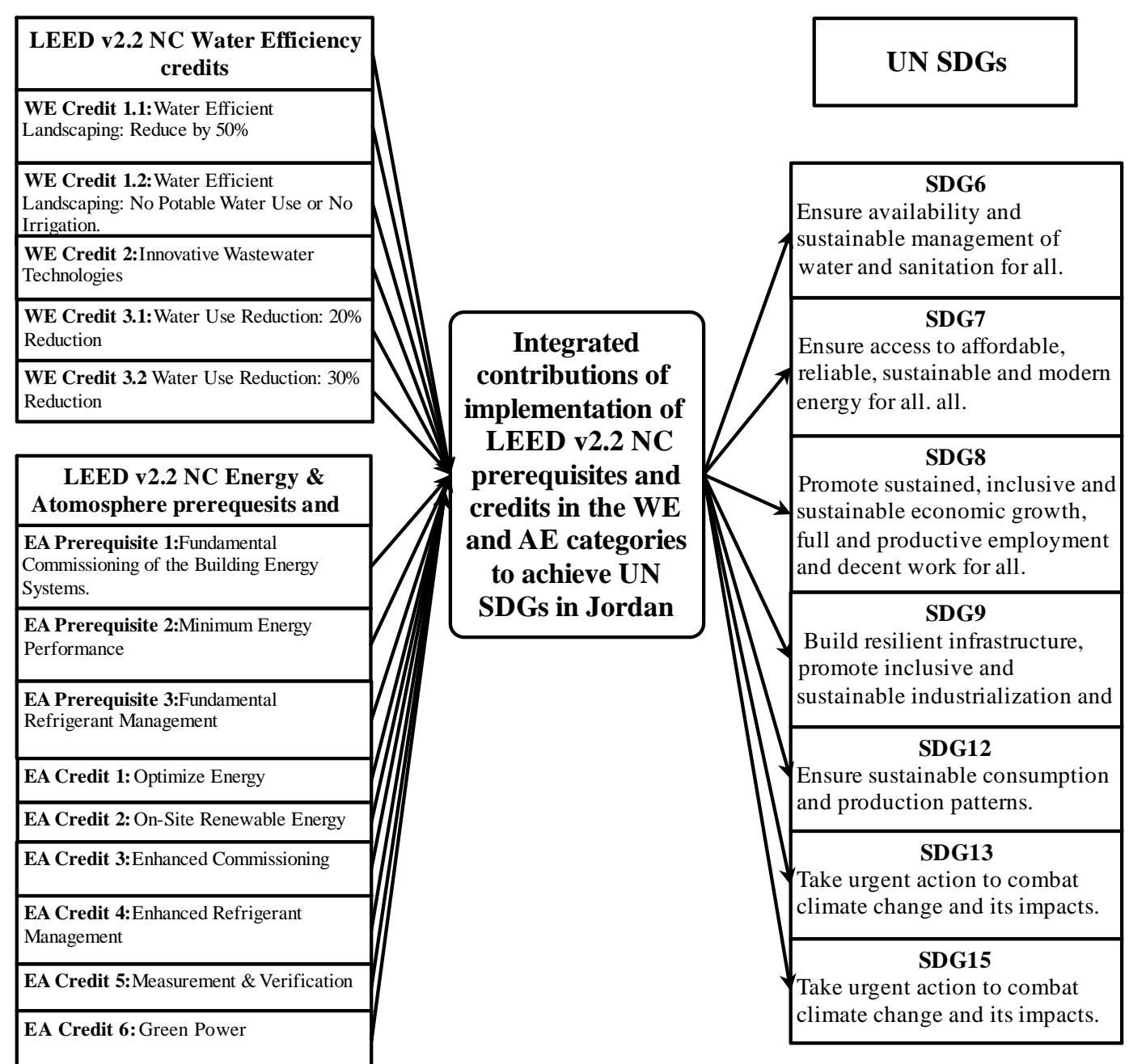

Fig. 3. Proposed integrated links between LEED v2.2 prerequisites and credits in the WE and EA categories and the UN SDGs.

\section{Research methodology}

This research is designed to explore if a relationship exists between LEED v2.2 prerequisite credits in two categories (WE and AE) and the UN SDGs and to develop a new index for assessing the contributions of water and energy efficiency in LEED v2.2certified buildings to achieve the UN SDGs in Jordan. Based on Kothari [36], descriptive research can include surveys and other forms of empirical inquiry.

The research methodology includes the two main hypotheses developed based on the literature review, as discussed in Section 2. A questionnaire was developed and distributed to the targeted audience. Data were gathered through a survey and analyzed with frequency, Pearson's Chi-square, and Cramer's V tests. Contribution indices were constructed. A focus group discussion was conducted to validate the results. The contribution indices were used to assess the contributions of water and energy efficiency in the two pioneer LEED-v2.2-certified buildings to achieve the UN SDGs in Jordan.

\subsection{Questionnaire development}

A questionnaire survey was used as the primary tool for data collection. It included statements and questions on data, age, job role, experience, and views on the contributions of the implementation of LEED v2.2 prerequisites and credits in the WE and EA to achieve the UN SDGs in Jordan. 
Generally, many response scale options were used by different researchers such as a dichotomous, three-point, five-point, and seven-point options. In most of the studies, the Likert five-point scale (1: strongly agree, 2: agree, 3: neither agree nor disagree, 4: disagree, 5: strongly disagree) was used to measure the level of agreement or disagreement. However, in most of these studies, categories 1 and 2 and 4 and 5 were combined to new categories "1: strongly agree/ agree" and "3: disagree/ strongly disagree," respectively. Category 3 (neither agree nor disagree) became category 2 because the aim of this study is not to test the degree of agreement regarding the relationship between each credit and prerequisite in the WE and EA categories and UN SDGs (the dichotomous scale is suitable to respond to the question if there is a significant relationship between LEED v2.2 prerequisites and credits in the WE and EA to achieve the UN SDGs in Jordan, as mentioned previously.)

A pilot study was conducted prior to the survey to test the comprehensibility and suitability of the questionnaire. The pilot study involved a team of three professors (academia), an associate professor, and three experts (consultancy firm and government authorities). All have experience with Jordan's built environment and green buildings. The questionnaire was finalized based on feedback from the pilot study.

\subsection{Data collection method}

The structured questionnaires were distributed to four groups of Jordanian building project experts (consultants, contractors, government officials, and academic experts). The main target was to select experts with professional qualifications, experience, knowledge on green building projects, and involvement in the Jordan Green Building Council. A total of 140 questionnaires were distributed and 55 participants completed the survey (39\%). The 55 responses were adequate compare with previous studies related to green buildings [37-40]. Darko et al. investigated major issues influencing the adoption of green building technologies from the perspectives of 33 US green building experts [37]. Hwang and $\mathrm{Ng}$ identified challenges faced by 30 project managers who work on the execution of green construction projects and determined knowledge areas and skills that are necessary to respond to such challenges [38]. Zhoa et al. conducted a survey with 30 project managers who were experienced in green construction to identify the leadership characteristics and styles of project managers in green building projects in Singapore [39]. Hwang and Tan identified common obstacles encountered by 31 experts during the management of green construction projects [36]. However, based on the central limit theorem, that is, a sample size above 30, statistical analysis could still be conducted [41]. In this research, 36\% of the respondents were from consultant companies, $31 \%$ from government authorities, $24 \%$ from contracting companies, and $9 \%$ from universities. The respondent demographics are shown in Table 1. Notably, there are few experts in Jordan who have more than 10 years of experience in sustainable construction or have a $\mathrm{PhD}$ in the field of sustainability. Available data and information on the two pioneer LEED-v2.2-certified green buildings in Amman (World Health Organization Building; Dutch Embassy) were collected. 
393

394 
Table 1. Respondent demographics

\begin{tabular}{|c|c|c|c|c|c|c|c|c|c|c|c|}
\hline \multirow[t]{2}{*}{ Items } & \multirow[t]{2}{*}{ Category } & \multicolumn{2}{|c|}{ Consultants } & \multicolumn{2}{|c|}{ Contractor } & \multicolumn{2}{|c|}{$\begin{array}{c}\text { Government } \\
\text { authorities }\end{array}$} & \multicolumn{2}{|c|}{ Universities } & \multicolumn{2}{|c|}{ Overall } \\
\hline & & No. & $\%$ & No. & $\%$ & No. & $\%$ & No. & $\%$ & No. & $\%$ \\
\hline \multirow[t]{2}{*}{ Respondents' gender } & Female & 11 & 65 & 4 & 29 & 7 & 37 & 3 & 60 & 25 & 45 \\
\hline & Male & 9 & 53 & 9 & 64 & 10 & 53 & 2 & 40 & 30 & 55 \\
\hline \multirow[t]{3}{*}{ Respondents 'age } & 20-30 years & 2 & 10 & 1 & 8 & 1 & 6 & & & 4 & 7 \\
\hline & $31-40$ years & 14 & 70 & 7 & 54 & 6 & 35 & 2 & 40 & 29 & 53 \\
\hline & $>40$ years & 4 & 20 & 5 & 38 & 10 & 59 & 3 & 60 & 22 & 40 \\
\hline \multirow[t]{2}{*}{ Respondents' education } & Bachelor & 10 & 59 & 12 & 86 & 11 & 58 & & & 33 & 60 \\
\hline & Master or $\mathrm{PhD}$ & 7 & 41 & 2 & 14 & 8 & 42 & 5 & 100 & 22 & 40 \\
\hline \multirow[t]{12}{*}{ Respondents' designation } & Architect & 2 & 10 & 1 & 8 & 1 & 6 & & & 4 & 7 \\
\hline & Senior architect & 4 & 20 & 1 & 8 & 2 & 12 & & & 7 & 13 \\
\hline & Senior civil engineer & 2 & 10 & 1 & 8 & 2 & 12 & & & 5 & 9 \\
\hline & Senior mechanical engineer & 3 & 15 & 2 & 15 & 1 & 6 & & & 6 & 11 \\
\hline & Senior electrical engineer & 4 & 20 & 2 & 15 & 2 & 12 & & & 8 & 15 \\
\hline & Project manager & 1 & 5 & 3 & 23 & 1 & 6 & & & 5 & 9 \\
\hline & General manager & 1 & 5 & 1 & 8 & & & & & 2 & 4 \\
\hline & Senior technical advisor & 1 & 5 & & & 3 & 18 & & & 4 & 7 \\
\hline & Senior manger & 1 & 5 & 1 & 8 & 2 & 12 & & & 4 & 7 \\
\hline & Managing director & 1 & 5 & 1 & 8 & 3 & 18 & & & 5 & 9 \\
\hline & Assistant professor & & & & & & & 2 & 40 & 2 & 4 \\
\hline & Associate professor & & & & & & & 3 & 60 & 3 & 5 \\
\hline \multirow[t]{3}{*}{ Respondents' experience } & $<5$ years & 2 & 10 & 1 & 8 & 1 & 6 & 1 & 20 & 5 & 9 \\
\hline & $5-10$ years & 5 & 25 & 3 & 23 & 4 & 24 & 1 & 20 & 13 & 24 \\
\hline & $>15$ years & 13 & 65 & 9 & 69 & 12 & 71 & 3 & 60 & 37 & 67 \\
\hline
\end{tabular}


The collected data were classified and tabulated prior to quantitative analysis (Table 2).

The hypotheses were tested to indicate if a relationship exists between LEED v2.2 credits in the WE and AE categories and the UN SDGs using Pearson's Chi-square and Cramer's V tests. The independent variables are LEED v2.2 prerequisites and credits in the WE and AE categories. The dependent variables are the UN SDGs 6, 7, 8, 9, 12, 13, and 15. Null hypotheses (no relationship between variables) were rejected at the $p$ $<0.05$ level. The nonparametric Chi-square metric was chosen because it is based on frequencies instead of parameters such as the unavailable means and standard deviations; there is no need for assumptions regarding the type of the population and parametric values and nonparametric tests are appropriate for ordinal or nominal scales.

Table 2 Statistical design

\begin{tabular}{llll}
\hline \# & Questions & $\begin{array}{l}\text { Measurement } \\
\text { level }\end{array}$ & Statistics \\
\hline Q1 & Gender & Nominal & Frequencies \\
\hline Q2 & Age & Scale & Frequencies \\
\hline Q3 & Designation & Nominal & Frequencies \\
\hline Q4 & Total years of work experience & Scale & Frequencies \\
\hline Q5 & $\begin{array}{l}\text { Contributions of the } \\
\text { implementation of LEED v2.2 WE } \\
\text { credits to achieve the UN SDGs }\end{array}$ & Ordinal & $\begin{array}{l}\text { Frequency, Chi- } \\
\text { square, and } \\
\text { Cramer's V tests }\end{array}$ \\
\hline & $\begin{array}{l}\text { Contributions of the } \\
\text { implementation of LEED v2.2 EA } \\
\text { prerequisites and credits to achieve } \\
\text { the UN SDGs }\end{array}$ & Ordinal & $\begin{array}{l}\text { Frequency, Chi- } \\
\text { square, and } \\
\text { Cramer's V tests }\end{array}$ \\
\hline
\end{tabular}

\subsection{Constructing the Contribution Indices}

The composite index is a mathematical tool (simple or complex) that aggregates 416 indicators, which is increasingly recognized as a practical method in policy analysis and public communication for the comparison of performances [42].

Generally, an aggregation method can be considered to be "simple" or "complex." We define an aggregation method as "simple" if an easily understandable mathematical function is used [42]. For example, the Human Development Index (HDI) developed by the United Nations Development Program is "a summary measure of average achievement in key dimensions of human development: a long and healthy life, being knowledgeable and having a decent standard of living. The HDI is the geometric mean of normalized indices for each of three key dimensions" [43].

The development of the contribution indices in this research is based on the data collected in the survey regarding the opinion of Jordan's experts on the contributions of the implementation of LEED v2.2 credits prerequisites in the WE and EA categories to achieve the UN SDGs. Following equations are proposed:

The Frequency Contribution of the Water Efficiency Index (FCWEI) is an index that describes the contribution percentage of each LEED v2.2 WE credit $\left(W E_{l}\right.$ : $W E_{c 1.1}$, 
$W E_{c 1.2}, W E_{c 2}, W E_{c 3.1}$, and $\left.W E_{c 3.2}\right)$ to achieve each UN SDGs $\left(S D G_{h}: S D G_{6}, S D G_{8}\right.$, $S D G_{9}, S D G_{12}, S D G_{13}$, and $S D G_{15}$ ).

$$
F C W E I_{W E_{l} \& S D G_{h}}=\text { Achievement } \% \times \frac{n_{W E_{l} \& S D G_{h}}}{N_{W E_{l} \& S D G_{h}}} \times 100
$$

The $F C W E I_{W E_{l} \& S D G_{h}}$ is the Frequency Contribution of the Water Efficiency Index; Achievement $\%$ is the percentage of the achievement of $W E_{l} ; n_{W E_{l} \& S D G_{h}}$ is the number of expert responses agreeing that the implementation of $W E_{l}$ can contribute to achieving $S D G_{h}$; and $N_{W E_{l} \& S D G_{h}}$ is the total number of expert responses on the contributions of the implementation of $W E_{l}$ to achieve $S D G_{h}$ in Jordan.

The Frequency Contribution of Energy and Atmosphere Index (FCEAI) is an index that describes the contribution percentage of each LEED v2.2 EA prerequisite and credit $\left(E A_{k}: E A_{P 1}, E A_{P 2}, E A_{P 3}, E A_{C 1}, E A_{C 2}, E A_{C 3}, E A_{C 4}, E A_{C 4}, E A_{C 5}, E A_{C 6}\right)$ to achieve each UN SDG (SDG $: S D G 7, S D G 8, S D G 9, S D G 12, S D G 13)$.

$$
F C E A I_{E A_{k} \& S D G_{i}}=\text { Acheivement } \% \times \frac{n_{E A_{k} \& S D G_{i}}}{N_{E A_{k} \& S D G_{i}}} \times 100,
$$

where the $F C E A I_{E A_{k} \& S D G_{i}}$ is the Frequency Contribution of Energy and Atmosphere Index; Achievement $\%$ is the percentage of achievement of $E A_{k} ; n_{E A_{k} \& S D G_{i}}$ is the number of expert responses agreeing that the implementation of $E A_{k}$ can contribute to achieving $S D G_{i}$; and $N_{E A_{k} \& S D G_{i}}$ is the total number of expert responses on the contributions of the implementation of $E A_{k}$ to achieving $S D G_{i}$ in Jordan.

The Multidimensional Contribution of Water Efficiency Index (MCWEI) is an integrated index that describes the overall contribution percentage of each LEED v2.2 WE credit $\left(W E_{l}: W E_{c 1.1}, W E_{c 1.2}, W E_{c 2}, W E_{c 3.1}\right.$, and $\left.W E_{c 3.2}\right)$ to achieve the UN SDGs 6, $8,9,12-13$, and 15 in Jordan. The geometric mean of the $F C W E I$ for each LEED v2.2 WE credit is used to calculate the MCWEI.

$$
\begin{aligned}
& M C W E I= \\
& \left(F C W E I_{W E_{l} \& S D G_{6}} \times F C W E I_{W E_{l} \& S D G_{8}} \times F C W E I_{W E_{l} \& S D G_{9}}\right. \\
& \times F C W E I_{W E_{l} \& S D G_{12}} \times F C W E I_{W E_{l} \& S D G_{13}} \\
& \left.\times F C W E I_{W E_{l} \& S D G_{15}}\right)^{1 / 6}
\end{aligned}
$$

The Multidimensional Contribution of Energy \& Atmosphere Index (MCEAI) is an integrated index that describes the overall contribution percentage of each LEED v2.2 EA prerequisite and credit $\left(E A_{k}: E A_{P 1}, E A_{P 2}, E A_{P 3}, E A_{C 1}, E A_{C 2}, E A_{C 3}, E A_{C 4}, E A_{C 4}, E A_{C 5}\right.$, $\left.E A_{C 6}\right)$ to achieve the UN SDGs 7-9, 12, and 13 in Jordan. The geometric mean of FCI for each LEED v2.2 EA prerequisite and credit is used to calculate the MCEAI.

$$
\begin{gathered}
M C E A I= \\
\left(F C E A I_{E A_{k} \& S D G_{7}} \times F C E A I_{E A_{k} \& S D G_{8}} \times F C E A I_{E A_{k} \& S D G_{9}}\right. \\
\left.\times F C E A I_{E A_{k} \& S D G_{12}} \times F C E A I_{E A_{k} \& S D G_{13}}\right)^{1 / 5}
\end{gathered}
$$

The Comprehensive Contribution to Development Index (CCDI) is a comprehensive index that describes the overall contribution percentage of all LEED v2.2 WE credits and EA prerequisites and credits to achieve the UN SDGs 6-9, 12-13, and 15 in Jordan. 
The mean MCWEI for each LEED v2.2 WE credit and MCEAI for each LEED v2.2 EA prerequisite and credit are used to calculate the $C C D I$.

Comprehensive Contributions to Development Index (CCDI)

$$
\begin{aligned}
& =\left(M C W E I_{W E c 1.1}+M C W E I_{W E c 1.2}+M C W E I_{W E c 2}\right. \\
& +M C W E I_{W E c 3.1}+M C W E I_{W E c 3.2}+M C E A I_{E A p 1} \\
& +M C E A I_{E A p 2}+M C E A I_{E A p 3}+M C E A I_{E A c 1}+M C E A I_{E A c 2} \\
& +M C E A I_{E A c 3}+M C E A I_{E A c 4} \\
& \left.+M C E A I_{E A C 5}+M C E A I_{E A c 6}\right) / 14
\end{aligned}
$$

This research introduces a new index to assess the contributions of the implementation of LEED v2.2 prerequisite credits in the WE and EA categories to achieve the UN SDGs.

Krueger, one of the leading researcher in focus group, described the focus group as "a carefully planned discussion designed to obtain perceptions on a defined area of interest in an open-minded, nonthreatening environment" [44]. Focus groups can be used both during preliminary or exploratory stages of a research project, where questions are explored and hypotheses are generated, and at later stages to assess the development, effectiveness, or impact of a program of activities [44].

A thorough manual on the use of focus groups in research has been published by the as "a research approach that has proven to be extremely useful in a wide variety of settings to rapidly and economically provide information on the range of opinions, knowledge, beliefs, and practices of a population" [45].

A focus group approach has been chosen for the validation of the results in this research. Krueger suggested a number of participants between five and ten [46]. In this research, ten participants, both male and female, were selected based on their expertise, role, and experience. The participants are Jordanian building-project experts (consultants, contractors, government officials, and academic experts from universities). They have theoretical and practical experience in green building projects.

3.6 Application of the CCDI for the assessment of the contributions of LEED-v2.2certified green buildings

To test the usability of CCDI for assessing the contributions water and energy efficiency Amman and the Dutch Embassy in Amman) were selected. 
the Dutch embassy. The building area is $1,253 \mathrm{~m}^{2}$ (including both existing and new areas for the main building and annexes).

\section{Results and Discussions}

4.1 Relationship between the UN SDGs and LEEDV2.2 credits in the WE category

The Pearson's Chi-square tests (Fig.4) show significant evidence of relationships between LEED v2.2 credits in the WE category and SDG6 $\left[\chi^{2}(\mathrm{df}=4, N=55)=35.568\right.$, $p<0.000]$, SDG8 $\left[\chi^{2}(\mathrm{df}=4, N=55)=32.387, p<0.000\right]$, SDG9 $\left[\chi^{2}(\mathrm{df}=4, N=55)\right.$ $=28.205, p<0.000], \mathrm{SDG} 12\left[\chi^{2}(\mathrm{df}=4, N=55)=20.398, p<0.000\right]$, SDG13 $\left[\chi^{2}(\mathrm{df}\right.$ $=4, N=55)=19.652, p<0.000]$, and SDG15 $\left[\chi^{2}(\mathrm{df}=4, N=55)=29.950, p<0.000\right]$. The results have a small $p$-value $(<0.05)$, which is strong evidence against null 519 hypotheses; therefore, we confirm all sub-hypotheses (H1A, H1B, H1C, H1D, H1E, and $\mathrm{H} 1 \mathrm{~F}$ ) and thus the main hypothesis $\mathrm{H} 1$. These findings are in line with previous 
Opinion of Jordan's experts about the contribution of the implementation of LEED v2.2 credits in the WE category to achieving the UN SDGs.

\begin{tabular}{|c|c|c|c|c|c|c|c|c|c|c|c|c|c|c|c|c|c|c|c|c|c|c|c|c|c|c|c|c|c|c|}
\hline \multirow{3}{*}{$\begin{array}{c}\begin{array}{c}\mathrm{WE} \\
\text { credit }\end{array} \\
\text { WE } 1.1\end{array}$} & \multicolumn{5}{|c|}{ SDG6 } & \multicolumn{5}{|c|}{ SDG8 } & \multicolumn{5}{|c|}{ SDG9 } & \multicolumn{5}{|c|}{ SDG12 } & \multicolumn{5}{|c|}{ SDG13 } & \multicolumn{5}{|c|}{ SDG15 } \\
\hline & \multicolumn{2}{|c|}{ Agree } & \multicolumn{2}{|c|}{ Disagree } & \multirow{2}{*}{$\begin{array}{c}\text { Total } \\
55\end{array}$} & \multicolumn{2}{|c|}{ Agree } & \multicolumn{2}{|c|}{ Disagree } & \multirow{2}{*}{$\begin{array}{c}\text { Total } \\
55\end{array}$} & \multicolumn{2}{|c|}{ Agree } & \multicolumn{2}{|c|}{ Disagree } & \multirow{2}{*}{$\begin{array}{c}\text { Total } \\
55\end{array}$} & \multicolumn{2}{|c|}{ Agree } & \multicolumn{2}{|c|}{ Disagree } & \multirow{2}{*}{$\begin{array}{c}\text { Total } \\
55\end{array}$} & \multicolumn{2}{|c|}{ Agree } & \multicolumn{2}{|c|}{ Disagree } & \multirow{2}{*}{$\begin{array}{c}\text { Total } \\
55\end{array}$} & \multicolumn{2}{|c|}{ Agree } & \multicolumn{2}{|c|}{ Disagree } & \multirow{2}{*}{$\begin{array}{c}\text { Total } \\
55\end{array}$} \\
\hline & 33 & $60 \%$ & 22 & $40 \%$ & & 28 & $51 \%$ & 27 & $49 \%$ & & 38 & $69 \%$ & 17 & $31 \%$ & & 29 & $53 \%$ & 26 & $47 \%$ & & 30 & $55 \%$ & 25 & $45 \%$ & & 29 & $53 \%$ & 26 & $47 \%$ & \\
\hline WE 1.2 & 42 & $76 \%$ & 13 & $24 \%$ & 55 & 37 & $67 \%$ & 18 & $33 \%$ & 55 & 42 & $76 \%$ & 13 & $24 \%$ & 55 & 32 & $58 \%$ & 23 & $42 \%$ & 55 & 33 & $60 \%$ & 22 & $40 \%$ & 55 & 33 & $60 \%$ & 22 & $40 \%$ & 55 \\
\hline WE 2 & 48 & $87 \%$ & 7 & $13 \%$ & 55 & 42 & $76 \%$ & 13 & $24 \%$ & 55 & 50 & $91 \%$ & 5 & $9 \%$ & 55 & 36 & $65 \%$ & 19 & $35 \%$ & 55 & 39 & $71 \%$ & 16 & $29 \%$ & 55 & 44 & $80 \%$ & 11 & $20 \%$ & 55 \\
\hline WE 3.1 & 51 & $93 \%$ & 4 & $7 \%$ & 55 & 48 & $87 \%$ & 7 & $13 \%$ & 55 & 52 & $95 \%$ & 3 & $5 \%$ & 55 & 42 & $76 \%$ & 13 & $24 \%$ & 55 & 44 & $80 \%$ & 11 & $20 \%$ & 55 & 46 & $84 \%$ & 9 & $16 \%$ & 55 \\
\hline WE 3.2 & 54 & $98 \%$ & 1 & $2 \%$ & 55 & 51 & $93 \%$ & 4 & $7 \%$ & 55 & 54 & $98 \%$ & 1 & $2 \%$ & 55 & 48 & $87 \%$ & 7 & $13 \%$ & 55 & 48 & $87 \%$ & 7 & $13 \%$ & 55 & 50 & $91 \%$ & 5 & $9 \%$ & 55 \\
\hline
\end{tabular}

Relationship between the LEED v2.2 prerequisites and credits in the WE category and UN SDGs.

\begin{tabular}{|c|c|c|c|c|}
\hline \multicolumn{3}{|c|}{ Independence test } & \multirow[b]{2}{*}{ Decision } & \multirow[b]{2}{*}{ Results } \\
\hline Cross tabulation & Chi-square test & $\begin{array}{c}\text { Cramer's V } \\
\text { coefficient }\end{array}$ & & \\
\hline Crosstab WE * SDG6 & $\chi^{2}(\mathrm{df}=4, N=55)=35.568, p<0.000$ & 0.36 & $\begin{array}{l}\text { Reject null } \\
\text { hypothesis }\end{array}$ & $\begin{array}{l}\text { H1 A confirmed: There is a strong } \\
\text { relationship between SDG6 and LEED v2.2 } \\
\text { WE credits }\end{array}$ \\
\hline Crosstab WE * SDG8 & $\chi^{2}(\mathrm{df}=4, N=55)=32.387, p<0.000$ & 0.343 & $\begin{array}{l}\text { Reject null } \\
\text { hypothesis }\end{array}$ & $\begin{array}{l}\text { H1B confirmed: There is a strong } \\
\text { relationship between SDG8 and LEED v2.2 } \\
\text { WE credits }\end{array}$ \\
\hline Crosstab WE * SDG9 & $\chi^{2}(\mathrm{df}=4, N=55)=28.205, p<0.000$ & 0.320 & $\begin{array}{l}\text { Reject null } \\
\text { hypothesis }\end{array}$ & $\begin{array}{c}\text { H1C confirmed: There is a strong } \\
\text { relationship between SDG9 and LEED v2.2 } \\
\text { WE credits }\end{array}$ \\
\hline Crosstab WE * SDG12 & $\chi^{2}(\mathrm{df}=4, N=5)=20.389, p<0.000$ & 0.271 & $\begin{array}{l}\text { Reject null } \\
\text { hypothesis }\end{array}$ & $\begin{array}{l}\text { H1D confirmed: There is a moderate } \\
\text { relationship between SDG12 and LEED } \\
\text { v2.2 WE credits }\end{array}$ \\
\hline Crosstab WE * SDG13 & $\chi^{2}(\mathrm{df}=4, N=55)=19.652, p<0.001$ & 0.267 & $\begin{array}{l}\text { Reject null } \\
\text { hypothesis }\end{array}$ & $\begin{array}{l}\text { H1E confirmed: There is a moderate } \\
\text { relationship between SDG13 and LEED } \\
\text { v2.2WE credits }\end{array}$ \\
\hline Crosstab WE * SDG15 & $\chi^{2}(\mathrm{df}=4, N=55)=29.950, p<0.001$ & 0.33 & $\begin{array}{l}\text { Reject null } \\
\text { hypothesis }\end{array}$ & $\begin{array}{l}\text { H1F confirmed: There is a strong } \\
\text { relationship between SDG15 and LEED } \\
\text { v2.2 WE credits }\end{array}$ \\
\hline
\end{tabular}

Fig.4 Relationship between the LEED v2.2 prerequisites and credits in the WE category and UN SDGs. 
The Pearson's chi-square tests (Fig.5) reveal significant evidence of strong relationships between LEED v2.2 prerequisites and credits in the EA category and SDG7 $\left[\chi^{2}(\mathrm{df}=4, N=55)=230.37, p<0.000\right]$, SDG8 $\left[\chi^{2}(\mathrm{df}=4, N=55)=111.148\right.$, $p<0.000]$, SDG9 $\left[\chi^{2}(\mathrm{df}=4, N=55)=54.351, p<0.000\right]$, SDG12 $\left[\chi^{2}(\mathrm{df}=4, N=55)\right.$ $=135.46, p<0.000]$, and SDG13 $\left[\chi^{2}(\mathrm{df}=4, N=55)=78.05, p<0.000\right]$. The results have a small $p$-value $(<0.05)$, which is strong evidence against null hypotheses; that LEED-certified green buildings address energy savings by reducing the amount of energy required for building operations and by utilizing clean and renewable energy. 
Opinion of Jordan's experts on the contribution of the implementation of LEED v2.2 prerequisites and credits in the EA category to achieving the UN SDGs.

\begin{tabular}{|c|c|c|c|c|c|c|c|c|c|c|c|c|c|c|c|c|c|c|c|c|c|c|c|c|c|}
\hline \multirow{3}{*}{$\begin{array}{c}\begin{array}{c}\text { EA } \\
\text { Credits }\end{array} \\
\text { EAp1 }\end{array}$} & \multicolumn{5}{|c|}{ SDG7 } & \multicolumn{5}{|c|}{ SDG8 } & \multicolumn{5}{|c|}{ SDG9 } & \multicolumn{5}{|c|}{ SDG12 } & \multicolumn{5}{|c|}{ SDG13 } \\
\hline & \multicolumn{2}{|c|}{ Agree } & \multicolumn{2}{|c|}{ Disagree } & \multirow{2}{*}{\begin{tabular}{|c} 
Total \\
55
\end{tabular}} & \multicolumn{2}{|c|}{ Agree } & \multicolumn{2}{|c|}{ Disagree } & \multirow{2}{*}{$\begin{array}{c}\text { Total } \\
55\end{array}$} & \multicolumn{2}{|c|}{ Agree } & \multicolumn{2}{|c|}{ Disagree } & \multirow{2}{*}{$\begin{array}{c}\text { Total } \\
55\end{array}$} & \multicolumn{2}{|c|}{ Agree } & \multicolumn{2}{|c|}{ Disagree } & \multirow{2}{*}{$\begin{array}{r}\text { Total } \\
55\end{array}$} & \multicolumn{2}{|c|}{ Agree } & \multicolumn{2}{|c|}{ Disagree } & \multirow{2}{*}{$\begin{array}{c}\text { Total } \\
55\end{array}$} \\
\hline & 45 & $82 \%$ & 10 & $18 \%$ & & 50 & $91 \%$ & 5 & $9 \%$ & & 47 & $85 \%$ & 8 & $15 \%$ & & 32 & $58 \%$ & 23 & $42 \%$ & & 35 & $64 \%$ & 20 & $36 \%$ & \\
\hline EAp2 & 30 & $55 \%$ & 25 & $45 \%$ & 55 & 25 & $45 \%$ & 30 & $55 \%$ & 55 & 40 & $73 \%$ & 15 & $27 \%$ & 55 & 40 & $73 \%$ & 15 & $27 \%$ & 55 & 43 & $78 \%$ & 12 & $22 \%$ & 55 \\
\hline EAp3 & 5 & $9 \%$ & 50 & $91 \%$ & 55 & 22 & $40 \%$ & 33 & $60 \%$ & 55 & 37 & $67 \%$ & 18 & $33 \%$ & 55 & 11 & $20 \%$ & 44 & $80 \%$ & 55 & 51 & $93 \%$ & 4 & $7 \%$ & 55 \\
\hline EAc1 & 52 & $95 \%$ & 3 & $5 \%$ & 55 & 51 & $93 \%$ & 4 & $7 \%$ & 55 & 53 & $96 \%$ & 2 & $4 \%$ & 55 & 52 & $95 \%$ & 3 & $5 \%$ & 55 & 50 & $91 \%$ & 5 & $9 \%$ & 55 \\
\hline EAc2 & 53 & $96 \%$ & 2 & $4 \%$ & 55 & 52 & $95 \%$ & 3 & $5 \%$ & 55 & 54 & $98 \%$ & 1 & $2 \%$ & 55 & 53 & $96 \%$ & 2 & $4 \%$ & 55 & 54 & $98 \%$ & 1 & $2 \%$ & 55 \\
\hline EAc3 & 46 & $84 \%$ & 9 & $16 \%$ & 55 & 42 & $76 \%$ & 13 & $24 \%$ & 55 & 30 & $55 \%$ & 25 & $45 \%$ & 55 & 32 & $58 \%$ & 23 & $42 \%$ & 55 & 30 & $55 \%$ & 25 & $45 \%$ & 55 \\
\hline EAc4 & 3 & $5 \%$ & 52 & $95 \%$ & 55 & 28 & $51 \%$ & 27 & $49 \%$ & 55 & 33 & $60 \%$ & 22 & $40 \%$ & 55 & 37 & $67 \%$ & 18 & $33 \%$ & 55 & 52 & $95 \%$ & 3 & $5 \%$ & 55 \\
\hline EAc5 & 47 & $85 \%$ & 8 & $15 \%$ & 55 & 39 & $71 \%$ & 16 & $29 \%$ & 55 & 41 & $75 \%$ & 14 & $25 \%$ & 55 & 52 & $95 \%$ & 3 & $5 \%$ & 55 & 36 & $65 \%$ & 19 & $35 \%$ & 55 \\
\hline EAc6 & 28 & $51 \%$ & 27 & $49 \%$ & 55 & 52 & $95 \%$ & 3 & $5 \%$ & 55 & 45 & $82 \%$ & 10 & $18 \%$ & 55 & 48 & $87 \%$ & 7 & $13 \%$ & 55 & 52 & $95 \%$ & 3 & $5 \%$ & 55 \\
\hline
\end{tabular}

Relationship between the LEED v2.2 prerequisites and credits in the EA category and UN SDGs.

\begin{tabular}{cccccc}
\hline Cross tabulation & Intendant test & Chi-square test & $\begin{array}{c}\text { Cramer's V } \\
\text { coefficient }\end{array}$ & Decision & Results \\
\hline Crosstab EA * SDG6 & $\chi^{2}(\mathrm{df}=4, N=55)=230.37, p<0.000$ & 0.682 & & $\begin{array}{c}\text { Reject null } \\
\text { hypothesis }\end{array}$ & $\begin{array}{c}\text { H2A confirmed: There is a strong } \\
\text { relationship between SDG7 and } \\
\text { LEED v2.2 EA prerequisites \& } \\
\text { credits }\end{array}$ \\
\hline Crosstab EA * SDG8 & $\chi^{2}(\mathrm{df}=4, N=55)=111.48, p<0.000$ & 0.474 & $\begin{array}{c}\text { Reject null } \\
\text { hypothesis }\end{array}$ & $\begin{array}{c}\text { H2B confired: There is a strong } \\
\text { relationship between SDG8 and } \\
\text { LEED v2.2 EA prerequisites \& } \\
\text { credits }\end{array}$ \\
\hline Crosstab EA * SDG9 & $\chi^{2}(\mathrm{df}=4, N=55)=54.351, p<0.000$ & 0.33 & $\begin{array}{c}\text { Reject null } \\
\text { hypothesis }\end{array}$ & $\begin{array}{c}\text { H2C confirmed: There is a strong } \\
\text { relationship between SDG9 and } \\
\text { LEED v2.2 EA prerequisites \& } \\
\text { credits }\end{array}$ \\
\hline Crosstab EA * SDG12 & $\chi^{2}(\mathrm{df}=4, N=5)=135.460, p<0.000$ & 0.523 & $\begin{array}{c}\text { Reject null } \\
\text { hypothesis }\end{array}$ & $\begin{array}{c}\text { H2D confirmed: There is a strong } \\
\text { relationship between SDG12 and } \\
\text { LEED v2.2 EA prerequisites \& } \\
\text { credits }\end{array}$ \\
\hline Crosstab EA * SDG13 & $\chi^{2}(\mathrm{df}=4, N=55)=78.05, p<0.001$ & 0.397 & $\begin{array}{c}\text { Reject null } \\
\text { hypothesis }\end{array}$ & $\begin{array}{c}\text { H2E confirmed: There is a strong } \\
\text { relationship between SDG13 and } \\
\text { LEED v2.2 EA prerequisites \& } \\
\text { credits }\end{array}$ \\
\hline
\end{tabular}

Fig.5 Relationship between the LEED v2.2 prerequisites and credits in the EA category and UN SDGs. 
Based on the results of the hypotheses tests, indices were developed to assess the

Based on the proposed MCDWEI, the LEED v2.2 WE credits are ranked as "WEc3.2:

Water Use Reduction: 30\% Reduction" (93.9), "WEc3.1: Water Use Reduction: 20\%

Based on the proposed MCDEAI, the LEED v2.2 prerequisites and credits in the EA 


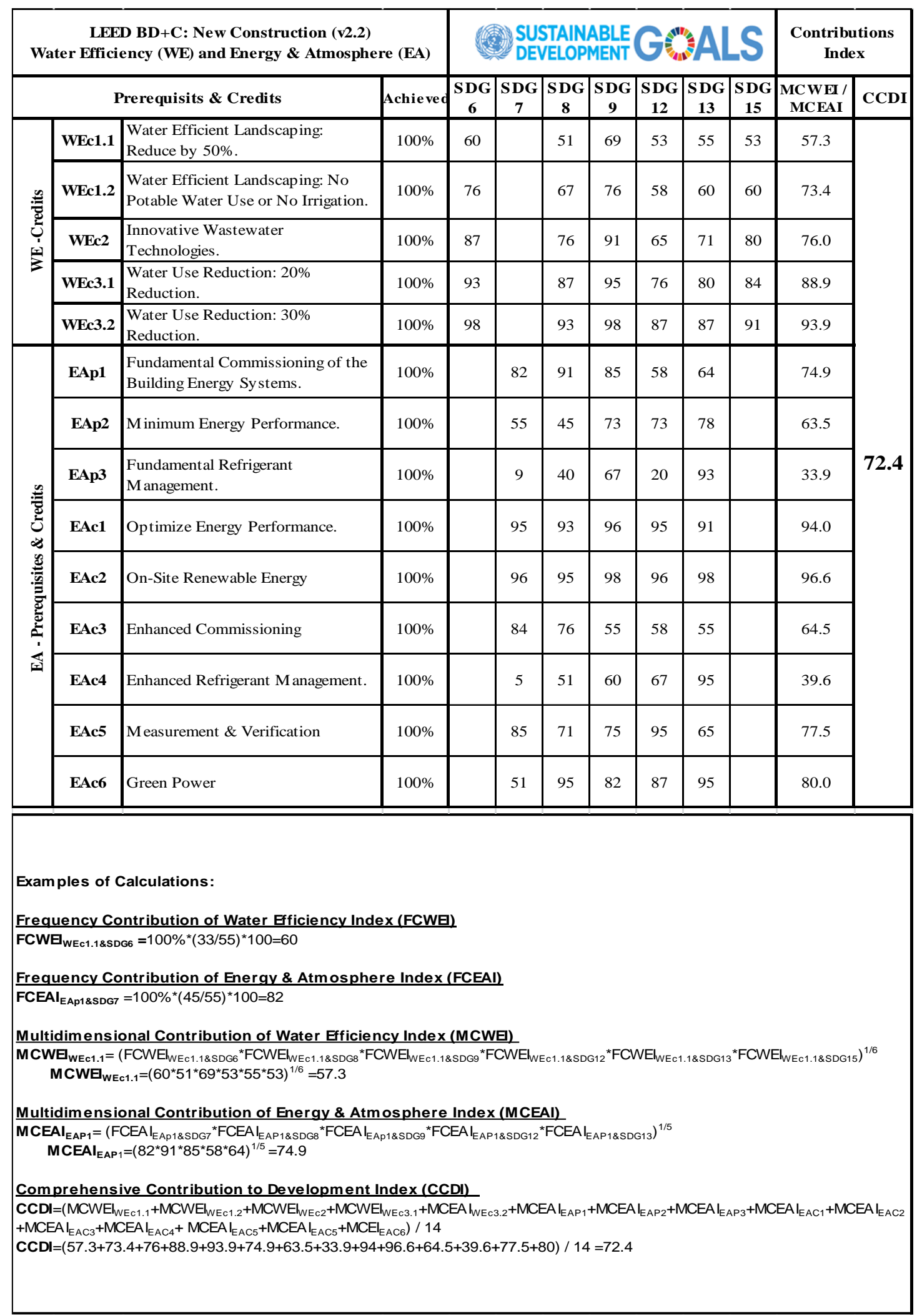

Fig. 6. Relationships between the LEED v2.2 prerequisites and credits in the WE and AE categories and UN SDGs in Jordan.

This section discusses the validation of the identified relationships between the UN

SDGs and LEEDV2.2 prerequisites and credits in the WE and EA categories and the 
4.4.1 Validation of identified relationships between the UN SDGs and LEEDV2.2 prerequisites and credits in the WE and EA categories

The results of this research on the relationship between the UN SDGs and LEEDV2.2 586 prerequisites and credits in the WE and EA categories in Jordan were presented during 587 focus group discussions. All participants were asked to reply with a yes/no answer 588 whether they think the results are reasonable and reliable.

The expert groups discussed the intent, cost, applicability, feasibility, and ease of implementation of the LEEDV2.2 prerequisites and credits in the WE and EA categories in Jordan. Furthermore, they discussed the targets of each UN SDG.

After a lengthy discussion, all experts agreed that the results are reasonable and reliable.

Table 3. Validation of identified relationships between the UN SDGs and LEEDV2.2 599 prerequisites and credits in the WE and EA categories 600

Question: What is your opinion of the results in this research? Are they reasonable?

\begin{tabular}{|c|c|c|c|c|}
\hline \multirow{3}{*}{$\begin{array}{l}\text { Relationship between the UN SDGs and } \\
\text { LEEDV2.2 prerequisites and credits in the } \\
\text { WE and EA categories }\end{array}$} & \multicolumn{4}{|c|}{ Focus group responses } \\
\hline & \multicolumn{2}{|c|}{ Yes } & \multicolumn{2}{|l|}{ NO } \\
\hline & Frequency & $\%$ & Frequency & $\%$ \\
\hline $\begin{array}{l}\text { There is a strong relationship between SDG6 and } \\
\text { LEED v } 2.2 \mathrm{WE} \text { credits. }\end{array}$ & 10 & 100 & 0 & 0 \\
\hline There is a strong relationship between SDG8 and & & & & \\
\hline $\begin{array}{l}\text { LEED v } 2.2 \text { WE credits. } \\
\text { There is a strong relationship between SDG9 and }\end{array}$ & 10 & 100 & 0 & 0 \\
\hline LEED v2.2 WE credits. & 10 & 100 & 0 & 0 \\
\hline $\begin{array}{l}\text { There is a moderate relationship between SDG12 } \\
\text { and LEED v } 2.2 \text { WE credits. }\end{array}$ & 10 & 100 & 0 & 0 \\
\hline $\begin{array}{l}\text { There is a moderate relationship between SDG13 } \\
\text { and LEED v2.2 WE credits. }\end{array}$ & 10 & 100 & 0 & 0 \\
\hline $\begin{array}{l}\text { There is a strong relationship between SDG15 } \\
\text { and LEED v } 2.2 \text { WE credit. }\end{array}$ & 10 & 100 & 0 & 0 \\
\hline $\begin{array}{l}\text { There is a strong relationship between SDG7 and } \\
\text { LEED v } 2.2 \text { EA prerequisites and credits. } \\
\text { There is a strong relationship between SDG8 and }\end{array}$ & 10 & 100 & 0 & 0 \\
\hline $\begin{array}{l}\text { LEED v2.2 EA prerequisites and credits. } \\
\text { There is a strong relationship between SDG9 and }\end{array}$ & 10 & 100 & 0 & 0 \\
\hline LEED v2.2 EA prerequisites and credits. & 10 & 100 & 0 & 0 \\
\hline $\begin{array}{l}\text { There is a strong relationship between SDG12 } \\
\text { and LEED v2.2 EA prerequisites and credits. } \\
\text { There is a strong relationship between SDG13 }\end{array}$ & 10 & 100 & 0 & 0 \\
\hline and LEED v2.2 EA prerequisites and credits. & 10 & 100 & 0 & 0 \\
\hline
\end{tabular}


The experts were also asked about their recommendations for further development. Table 4 presents the responses of the focus group.

All ten $(100 \%)$ focus group members agreed that the contribution indices are easy to understand and compatible with Jordan's environment and conditions. They will provide a robust assessment of the contribution of the water and energy efficiency of LEED v2.2 certified-buildings to achieve the UN SDGs. They also agreed that the contribution indices will help to understand how water and energy efficiency in green buildings can contribute to achieving the UN SDGs in Jordan.

Nine $(90 \%)$ focus group members agreed that the methodology used to construct the contribution indices is reliable. They recommended other researchers and policy makers to use this methodology to develop a new assessment method for the contribution of water and energy efficiency in green buildings for other versions of LEED or other green building assessment systems. Only one expert was not sure if this methodology can be used to construct contribution indices. Therefore, the contribution indices were validated.

Table 4. Validation of the Contribution Indices

\begin{tabular}{l} 
Question \\
\hline 1 The contribution indices are ... ? \\
2 The contribution indices will provide a \\
robust assessment for the contribution of \\
the water and energy efficiency in LEED \\
v2.2-certified buildings to achieve the \\
UN SDGs.
\end{tabular}

3 The contribution indices measures are compatible with Jordan's environment and conditions.

Yes

4 The contribution indices will help to understand how water and energy efficiency in green buildings can contribute to achieving the UN SDGs in Jordan.

5 The methodology used to construct the contribution indices is reliable and will guide researchers and policy maker in developing new assessment methods for Frequen $\%$ cy

$\begin{array}{lcc}\text { Easy to understand } & 10 & 100 \\ \text { Difficult to understand } & 0 & 0 \\ \text { Neither easy nor } & 0 & 0 \\ \text { difficult to understand } & & \\ \text { Yes } & 10 & 100 \\ \text { No } & 0 & 0 \\ \text { Not sure } & 0 & 0 \\ & & \\ \text { Yes } & & \\ \text { No } & 10 & 100 \\ \text { Not sure } & & 0 \\ \text { Yes } & & 0 \\ \text { No } & 10 & 100 \\ \text { Not sure } & 0 & 0 \\ & 0 & 0\end{array}$
the contribution of water and energy efficiency in green buildings for other versions of LEED or other green building assessment systems.

4.5 Assessing the contributions of LEED-v2.2-certified green buildings to achieve the

An assessment of the contributions of water and energy efficiency in the two pioneer LEED-v2.2-certified green buildings to achieve the UN SDGs in Jordan was conducted to determine the usability of the CCDI for the assessment and comparison of the 
Figs 7 and 8 show that the LEED v2.2 WE and EA prerequisites and credits in the two pioneer LEED-v2.2-certified buildings (WHO building and Dutch embassy in Amman) contribute to achieving SDG6, SDG7, SDG8, SDG9, SDG12, SDG13, and SDG15 in Jordan. The CCDI values for the WHO building in Amman is 51.2, while that for the Dutch embassy in Amman is 39.6. This indicates that the WHO building in Amman contributes more to achieving the UN SDGs in Jordan. The MCWEI and MCEAI values significantly affect the CCDI value. One of the most interesting results is that the contributions of the water and energy efficiency in LEED green buildings to achieve the UN SDGs can be improved if priority is given to the implementation of WE and EA credits with high MCWEI and MCEAI values.

\begin{tabular}{|c|c|c|c|c|c|c|c|c|c|c|c|c|}
\hline \multicolumn{13}{|c|}{$\begin{array}{l}\text { World Health Organization Building } \\
\text { GOLD, AWARDED DEC } 2011\end{array}$} \\
\hline \multicolumn{4}{|c|}{$\begin{array}{l}\text { LEED BD+C: New Construction (v2.2) } \\
\text { Water Efficiency (WE) and Energy \& Atmosphere (EA) }\end{array}$} & \multicolumn{7}{|c|}{$\begin{array}{l}\text { SUSTAINABLE } \\
\text { SEVELOPMENT }\end{array}$} & \multicolumn{2}{|c|}{$\begin{array}{c}\text { Contributions } \\
\text { Index }\end{array}$} \\
\hline \multicolumn{3}{|r|}{ Prerequisits \& Credits } & Achieved & $\begin{array}{c}\text { SDG } \\
6\end{array}$ & $\begin{array}{c}\text { SDG } \\
7\end{array}$ & \begin{tabular}{|c} 
SDG \\
8
\end{tabular} & $\begin{array}{c}\text { SDG } \\
9\end{array}$ & \begin{tabular}{|c|} 
SDG \\
12
\end{tabular} & \begin{tabular}{|c} 
SDG \\
13
\end{tabular} & $\begin{array}{c}\text { SDG } \\
15\end{array}$ & MCDI & CCDI \\
\hline \multirow{5}{*}{ 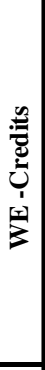 } & WEc1.1 & $\begin{array}{l}\text { Water Efficient Landscaping: } \\
\text { Reduce by } 50 \% \text {. }\end{array}$ & $100 \%$ & 60 & & 51 & 69 & 53 & 55 & 53 & 57.3 & \multirow{14}{*}{51.2} \\
\hline & WEc1.2 & $\begin{array}{l}\text { Water Efficient Landscaping: No } \\
\text { Potable Water Use or No Irrigation. }\end{array}$ & $100 \%$ & 76 & & 67 & 76 & 58 & 60 & 60 & 73.4 & \\
\hline & WEc2 & $\begin{array}{l}\text { Innovative Wastewater } \\
\text { Technologies. }\end{array}$ & $100 \%$ & 87 & & 76 & 91 & 65 & 71 & 80 & 76.0 & \\
\hline & WEc3.1 & $\begin{array}{l}\text { Water Use Reduction: } 20 \% \\
\text { Reduction. } \\
\end{array}$ & $100 \%$ & 93 & & 87 & 95 & 76 & 80 & 84 & 88.9 & \\
\hline & WEc3.2 & $\begin{array}{l}\text { Water Use Reduction: } 30 \% \\
\text { Reduction. }\end{array}$ & $100 \%$ & 98 & & 93 & 98 & 87 & 87 & 91 & 93.9 & \\
\hline \multirow{9}{*}{ 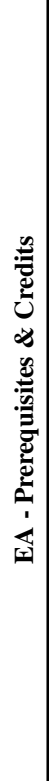 } & EAp1 & $\begin{array}{l}\text { Fundamental Commissioning of the } \\
\text { Building Energy Systems. }\end{array}$ & $100 \%$ & & 82 & 91 & 85 & 58 & 64 & & 74.9 & \\
\hline & EAp2 & Minimum Energy Performance. & $100 \%$ & & 55 & 45 & 73 & 73 & 78 & & 63.5 & \\
\hline & EAp3 & $\begin{array}{l}\text { Fundamental Refrigerant } \\
\text { Management. }\end{array}$ & $100 \%$ & & 9 & 40 & 67 & 20 & 93 & & 33.9 & \\
\hline & EAc1 & Optimize Energy Performance. & $40 \%$ & & 95 & 93 & 96 & 95 & 91 & & 37.6 & \\
\hline & EAc2 & On-Site Renewable Energy & $0 \%$ & & 96 & 95 & 98 & 96 & 98 & & 0.0 & \\
\hline & EAc3 & Enhanced Commissioning & $0 \%$ & & 84 & 76 & 55 & 58 & 55 & & 0.0 & \\
\hline & EAc4 & Enhanced Refrigerant Management. & $100 \%$ & & 5 & 51 & 60 & 67 & 95 & & 39.6 & \\
\hline & EAc5 & Measurement \& Verification & $100 \%$ & & 85 & 71 & 75 & 95 & 65 & & 77.5 & \\
\hline & EAc6 & Green Power & $0 \%$ & & 51 & 95 & 82 & 87 & 95 & & 0.0 & \\
\hline
\end{tabular}

Fig. 7. Contribution of an LEED-v2.2-certified building (WHO building in Amman) 


\begin{tabular}{|c|c|c|c|c|c|c|c|c|c|c|c|c|}
\hline \multicolumn{13}{|c|}{$\begin{array}{l}\text { Dutch Embassy in Amman, Jordan } \\
\text { SILVER, AWARDED OCT } 2010\end{array}$} \\
\hline \multicolumn{4}{|c|}{$\begin{array}{l}\text { LEED BD+C: New Construction (v2.2) } \\
\text { Water Efficiency (WE) and Energy \& Atmosphere (EA) }\end{array}$} & \multicolumn{7}{|c|}{$\begin{array}{l}\text { SUSTAINABLE } \\
\text { DEVELOPMENT }\end{array}$} & \multicolumn{2}{|c|}{$\begin{array}{l}\text { Contributions } \\
\text { Index }\end{array}$} \\
\hline \multicolumn{3}{|r|}{ Prerequisits \& Credits } & Achieved & $\begin{array}{c}\text { SDG } \\
6\end{array}$ & $\begin{array}{c}\text { SDG } \\
7\end{array}$ & \begin{tabular}{|c} 
SDG \\
8
\end{tabular} & $\begin{array}{c}\text { SDG } \\
9\end{array}$ & $\begin{array}{c}\text { SDG } \\
12\end{array}$ & $\begin{array}{c}\text { SDG } \\
13\end{array}$ & $\begin{array}{c}\text { SDG } \\
15\end{array}$ & MCDI & CCDI \\
\hline \multirow{5}{*}{ 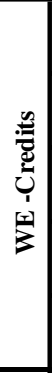 } & WEc1.1 & $\begin{array}{l}\text { Water Efficient Landscaping: } \\
\text { Reduce by } 50 \% \text {. }\end{array}$ & $100 \%$ & 60 & & 51 & 69 & 53 & 55 & 53 & 57.3 & \multirow{14}{*}{39.6} \\
\hline & WEc1.2 & $\begin{array}{l}\text { Water Efficient Landscaping: No } \\
\text { Potable Water Use or No Irrigation. }\end{array}$ & $0 \%$ & 76 & & 67 & 76 & 58 & 60 & 60 & 0.0 & \\
\hline & WEc2 & $\begin{array}{l}\text { Innovative Wastewater } \\
\text { Technologies. }\end{array}$ & $0 \%$ & 87 & & 76 & 91 & 65 & 71 & 80 & 0.0 & \\
\hline & WEc3.1 & $\begin{array}{l}\text { Water Use Reduction: } 20 \% \\
\text { Reduction. }\end{array}$ & $100 \%$ & 93 & & 87 & 95 & 76 & 80 & 84 & 88.9 & \\
\hline & WEc3.2 & $\begin{array}{l}\text { Water Use Reduction: } 30 \% \\
\text { Reduction. }\end{array}$ & $100 \%$ & 98 & & 93 & 98 & 87 & 87 & 91 & 93.9 & \\
\hline \multirow{9}{*}{ 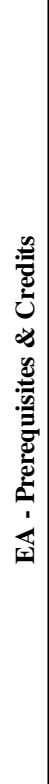 } & EAp1 & $\begin{array}{l}\text { Fundamental Commissioning of the } \\
\text { Building Energy Systems. }\end{array}$ & $100 \%$ & & 82 & 91 & 85 & 58 & 64 & & 74.9 & \\
\hline & EAp2 & Minimum Energy Performance. & $100 \%$ & & 55 & 45 & 73 & 73 & 78 & & 63.5 & \\
\hline & EAp3 & $\begin{array}{l}\text { Fundamental Refrigerant } \\
\text { Management. }\end{array}$ & $100 \%$ & & 9 & 40 & 67 & 20 & 93 & & 33.9 & \\
\hline & EAc1 & Optimize Energy Performance. & $40 \%$ & & 95 & 93 & 96 & 95 & 91 & & 37.6 & \\
\hline & EAc2 & On-Site Renewable Energy & $67 \%$ & & 96 & 95 & 98 & 96 & 98 & & 64.4 & \\
\hline & EAc3 & Enhanced Commissioning & $0 \%$ & & 84 & 76 & 55 & 58 & 55 & & 0.0 & \\
\hline & EAc4 & Enhanced Refrigerant Management. & $100 \%$ & & 5 & 51 & 60 & 67 & 95 & & 39.6 & \\
\hline & EAc5 & Measurement \& Verification & $0 \%$ & & 85 & 71 & 75 & 95 & 65 & & 0.0 & \\
\hline & EAc6 & Green Power & $0 \%$ & & 51 & 95 & 82 & 87 & 95 & & 0.0 & \\
\hline
\end{tabular}

Fig. 8. Contribution of an LEED-v2.2-certified building (Dutch embassy in Amman) to achieving the UN SDGs in Jordan.

\section{Conclusion}

Governments across the world have developed strategies to meet UN SDGs and green buildings have an important role to play in this respect. Water and energy efficiency in building has a critical role towards achieving UN SDGs. Governments, designers and developers need to be better informed about the advantages of invest in water and energy efficiency measures in green buildings to maximize the contribution towards achieving UN SDGs. Presently, there is lack of information and understanding on the subject as none of the existing green buildings assessment tools describe the relationship between its water and energy efficiency indicators and UN SDGs. There is thus a need for a methodology to assess and improve the contribution of water and energy efficiency in achieving UN SDGs. This study attempts to bridge this gap in the scholarship. It is the first research to identify the contributions of the implementation of LEED v2.2 prerequisites and credits in the WE and EA categories to achieve the UN 
SDGs. It proposes an index for the assessment of the contribution of water and energy efficiency in LEED-v2.2-certified green buildings to achieve the UN SDGs in Jordan. The proposed index can help governments, designers and developers to priorities their strategies and optimally allocate resources to achieve the UN SDGs through water and energy efficiency measures. The proposed index can be used by researchers in Jordan and elsewhere in the world to develop a new assessment method for the contribution of the water and energy efficiency in green buildings for other LEED versions or other green building assessment systems. It is found that the implementation of LEED v2.2 WE credit and AE prerequisites and credits contributes to achieving seven UN SDGs in Jordan: SD6, SDG7, SDG8, SDG9, SDG12, SDG13, and SDG15. The tests of all between the UN SDGs and LEED v2.2 credits in the WE category and there is a significant relationship between the UN SDGs and LEED v2.2 prerequisites and credits in the EA category. The contributions of water and energy efficiency in the two pioneer LEED-v2.2-certified green buildings to achieving the UN SDGs in Jordan were assessed. The CCDI values are 51.2 for the WHO building in Amman and 39.6 for the Dutch embassy in Amman. This indicates that the WHO building in Amman contributes more to achieving the UN SDGs in Jordan. The MCWEI and MCEAI help to understand which credit or prerequisite of the LEED v2.2 WE and EA categories contribute the most to achieving the UN SDGs. It is concluded that the indices are useful tools for the assessment of the contribution of the water and energy efficiency on the building scale level.

Acknowledgements

We did not receive any specific grant from funding agencies in the public, commercial, or not-for-profit sectors.

\section{References}

[1] United Nations, "Sustainable Development Goals". 1086, https://doi.org/10.1016/j.buildenv.2010.11.009.

[7] Environmental Protection Agency, Green Building, 
[8] L Shen, H Yan, H Fan, Y Wu, Y Zhang, An integrated system of text mining

technique and case-based reasoning (TM-CBR) for supporting green building design ,

Building and Environment Volume 124, 1 November 2017, Pages 388-401,

[9] World Green Building Council, Green building \& the Sustainable Development

Goals, http://www.worldgbc.org/green-building-sustainable-development-goals, 2018 (accessed 27 May 2018).

[10] Hikmat H. Ali , Saba F. Al Nsairat, Developing a green building assessment tool for developing countries - Case of Jordan, Building and Environment 44 (2009)

1053-1064, https://doi.org/10.1016/j.buildenv.2008.07.015

[11] I. M. Chethana S. Illankoon; Vivian W. Y. Tam, Ph.D.; and Khoa N. Le, Ph.D.,

Rating Tools, ASCE 05016010-1, https://doi.org/10.1061/(ASCE)EI.1943-

[12] Eduard Cubi Montanya and David Keith. 2011. "LEED, Energy Savings, and

Carbon Abatement: Related but Not Synonymous." Environmental Science and

Technology, 45, Pp. 1757-1758, DOI: 10.1021/es1041332

[13] Latif Onur Uğura, Neşe Leblebicib , An examination of the LEED green building certification system in terms of construction costs, Renewable and Sustainable Energy Reviews 81 (2018) 1476-1483

[14] F. Asdrubali, G. Baldinelli* , F. Bianchi, S. Sambuco, A comparison between environmental sustainability rating systems LEED and ITACA for residential

[16] U.S. Green Building Council, LEED for New Construction \& 
[23] US Green Building Council, projects, Dutch Embassy in Amman

May 2018).

[24] US Green Building Council, projects, Middle East Insurance Building 769

https://www.usgbc.org/projects/middle-east-insurance-building, 2018 (accessed $27 \quad 770$

May 2018).

[25] US Green Building Council, projects, ATG Headquarter Building,

https://www.usgbc.org/projects/atg-head-quarter, 2018 (accessed 27 May 2018).

[26] Hashemite Kingdom of Jordan, Ministry of Water and Irrigation, National Water Strategy of Jordan, 2016 - 2025, http://www.mwi.gov.jo/sites/en-

us/Hot\%20Issues/Strategic\%20Documents\%20of\%20\%20The\%20Water\%20Sector/

National\%20Water\%20Strategy(\%202016-2025)-25.2.2016.pdf, 2018 (accessed 27

May 2018).

[27] Nidal Hadadin, Maher Qaqish, Emad Akawwi, Ahmed Bdour, Water shortage in

Jordan — Sustainable solutions, Desalination 250 (2010) 197-202,

https://doi.org/10.1016/j.desal.2009.01.026

[28] LEED for New Construction \& Major Renovations, version 2.2,

https://www.usgbc.org/Docs/Archive/General/Docs1095.pdf, 2018 (accessed 27 May 2018).

[29] Green Outlook 2011, Green Trends Driving Growth (McGraw-Hill Construction, 2010), aiacc.org/wp-content/uploads/2011/06/greenoutlook2011.pdf , 2018 (accessed 27 May 2018).

[30] J.O., Jaber , Fawwaz Elkarmi , Emil Alasis , Anagnostopoulos Kostas ,

Employment of renewable energy in Jordan: Current status, SWOT and problem 
[37] Amos Darko, Albert Ping, Chuen Chan, Ernest Effah, Ameyaw Bao-Jie, He Ayokunle Olubunmim Olanipekun, Examining issues influencing green building technologies adoption: The United States green building experts' perspectives, Energy and Buildings, Volume 144, 1 June 2017, Pages 320-332, https://doi.org/10.1016/j.enbuild.2017.03.060

[38] Hwang, B. G., and Ng, W. J. (2013). Project management knowledge and skills for green construction: Overcoming challenges. International Journal of Project Management,(31) 2,272-284, https://doi.org/10.1016/j.ijproman.2012.05.004

- [39] Zhao, X., Hwang, B. G., and Lee, H. N. (2016). Identifying critical leadership

[40] Hwang, B. G., and Tan, J. S. (2012). Green building project management: obstacles and solutions for sustainable development. Sustainable Development, 20(5),

[41] Ott, R. L., and Longnecker, M. (2001). An introduction to statistical methods and data 1061 analysis. Duxbury (MA): Pacific Grove.

[42] Saisana, M., and S. Tarantola. 2002. State-of-the-art Report on Current pdf , 2018 (accessed 27 May 2018).

[43] United Nations Development Programme , HumanDevelopment Reports, Human 